\title{
Phytoprotection
}

\section{The mycoherbicide Atlernaria cassiae infects and alters phenolic metabolism of Cassia alata seedlings}

\section{R.E. Hoagland}

Volume 76, numéro 2, 1995

URI : https://id.erudit.org/iderudit/706086ar

DOI : https://doi.org/10.7202/706086ar

Aller au sommaire du numéro

Éditeur(s)

Société de protection des plantes du Québec (SPPQ)l

ISSN

0031-9511 (imprimé)

1710-1603 (numérique)

Découvrir la revue

Citer cet article

Hoagland, R. (1995). The mycoherbicide Atlernaria cassiae infects and alters phenolic metabolism of Cassia alata seedlings. Phytoprotection, 76(2), 67-74. https://doi.org/10.7202/706086ar

\section{Résumé de l'article}

Le mycoherbicide Alternaria cassiae, un agent pathogène du Cassia obtusifolia a infecté le Cassia alata, une espèce de Cassia jamais testée auparavant. Quand des plantules de $C$. alata âgées de 2 semaines et cultivées en cabinets de croissance ont été inoculées avec $10^{5}$ spores $\mathrm{mL}^{-1}$ suivi d'une période d'humectation de $12 \mathrm{~h}$, l'infection était apparente 16-20 $\mathrm{h}$ après le traitement. La sévérité de l'infection était proportionnelle à la concentration de spores, $10^{6}$ spores $\mathrm{mL}^{-1}$ entraînant une mortalité complète $4-5$ jours après le traitement. L'âge des plantes influençait la gravité de la maladie et l'efficacité du mycoherbicide. À $10^{6}$ spores $\mathrm{mL}^{-1}, 95 \%$ des plantes âgées de 1-3 semaines étaient mortes, et les survivantes montraient des dommages graves; les plantes âgées de 3-4 semaines présentaient des lésions multiples, une réduction de croissance et une chute des feuilles. Finalement les plantes âgées de 5-7 semaines étaient infectées et présentaient plusieurs lésions mais elles ont repris le dessus sur la maladie. La quantité de phénylalanine-ammonia-lyase extractible des plantules de $C$. alata traitées était trois fois plus élevée que chez les plantules non traitées 17-96 $\mathrm{h}$ après l'application des spores. Les niveaux d'hydroxyphénols solubles étaient aussi plus élevés dans les plantules traitées à l'A cassiae, mais seulement 48-96 h après le traitement. Les résultats indiquent que la gamme d'hôtes de cet agent pathogène est très large, et suggèrent que le métabolisme des composés phénoliques est accéléré en réponse à l'invasion par l'agent pathogène. 


\title{
The mycoherbicide Alternaria cassiae infects and alters phenolic metabolism of Cassia alata seedlings
}

\author{
Robert E. Hoagland ${ }^{1}$
}

Received 1994-10-11; accepted 1995-09-13

The mycoherbicide Alternaria cassiae, a pathogen of the weed sicklepod (Cassia obtusifolia), was found to infect a previously untested Cassia species, Cassia alata (ringworm bush or seven golden candlesticks). When 2-wk-old, growth chamber-grown $C$. alata seedlings were inoculated with $10^{5}$ spores $\mathrm{mL}^{-1}$ followed by a 12-h dew period, infection was apparent 16-20 $\mathrm{h}$ after treatment. Infection severity was proportional to spore concentration, and $10^{6}$ spores $\mathrm{mL}^{-1}$ caused complete mortality 4-5 d after treatment. Plant age was also a factor in disease severity and mycoherbicidal efficacy. At $10^{6}$ spores $\mathrm{mL}^{-1}, 95 \%$ of 1- to 3-wk-old seedlings were killed (with severe damage to others); 3 - to 4-wk-old plants had multiple lesions, growth reduction, and some leaf abscission; and 5- to 7-wk-old plants were infected with many lesions, but they outgrew these effects. Extractable phenylalanine ammonia-lyase in treated C. alata seedlings was increased three-fold above that of untreated seedlings 17-96 $\mathrm{h}$ after spore application. Soluble hydroxyphenolic levels were also increased in the $A$. cassiae-treated seedlings, but not until 48-96 h after treatment. Results indicate an expanded host range for this plant pathogen and suggest that phenolic metabolism is increased in defense of pathogen invasion.

Hoagland, R.E. 1995. Le mycoherbicide Alternaria cassiae infecte et altère le métabolisme phénolique des plantules de Cassia alata. PHYTOPROTECTION 76 : 67-74.

Le mycoherbicide Alternaria cassiae, un agent pathogène du Cassia obtusifolia a infecté le Cassia alata, une espèce de Cassia jamais testée auparavant. Quand des plantules de $C$. alata âgées de 2 semaines et cultivées en cabinets de croissance ont été inoculées avec $10^{5}$ spores $\mathrm{mL}^{-1}$ suivi d'une période d'humectation de $12 \mathrm{~h}$, l'infection était apparente $16-20 \mathrm{~h}$ après le traitement. La sévérité de l'infection était proportionnelle à la concentration de spores, $10^{6}$ spores $\mathrm{mL}^{-1}$ entraînant une mortalité complète $4-5$ jours après le traitement. L'âge des plantes influençait la gravité de la maladie et l'efficacité du mycoherbicide. A $10^{6}$ spores $\mathrm{mL}^{-1}, 95 \%$ des plantes âgées de 1-3 semaines étaient mortes, et les survivantes montraient des dommages graves; les plantes âgées de 3-4 semaines présentaient des lésions multiples, une réduction de croissance et une chute des feuilles. Finalement les plantes âgées de 5-7 semaines étaient infectées et présentaient plusieurs lésions mais elles ont repris le dessus sur la maladie. La quantité de phénylalanine-ammonia-lyase extractible des plantules de $C$. alata traitées était trois fois plus élevée que chez les plantules non traitées 17-96 h après l'application des spores. Les niveaux d'hydroxyphénols solubles étaient aussi plus élevés dans les plantules traitées

1. USDA-ARS, Southern Weed Science Laboratory, P.O. Box 350, Stoneville, Mississippi, U.S.A. 38776 
à I'A. cassiae, mais seulement 48-96 h après le traitement. Les résultats indiquent que la gamme d'hôtes de cet agent pathogène est très large, et suggèrent que le métabolisme des composés phénoliques est accéléré en réponse à l'invasion par l'agent pathogène.

\section{INTRODUCTION}

Alternaria cassiae Jurair and Khan is a dematiaceous hyphomycetous fungus originally isolated from sicklepod (Cassia obtusifolia L.) in Pakistan (Jurair and Khan 1960). It has since been reported in many parts of the southern United States, and its effectiveness as a mycoherbicide for the biological control of sicklepod has been demonstrated (Walker and Boyette 1985; Walker and Riley 1982). Sicklepod is a non-nodulating leguminous weed of increasing economic importance in soybean- (Glycine max Merr.), cotton- (Gossypium hirsutum L.), and peanut- (Arachis hypogaea L.) producing areas of the southeastern United States (Buchanan and Burns 1971; Gossett 1981; Hauser et al. 1975). In greenhouse tests, $A$. cassiae infected showy crotalaria (Crotalaria spectabilis Roth.) and one other species of Cassia, coffee senna (Cassia occidentalis L.), but did not infect 30 other crop and weed species (Walker 1982). Thus far, there appears to be no other reports of Cassia species tested for interactions with this organism.

Cassia alata L., commonly called ringworm bush or seven golden candlesticks, is a perennial legume found in damp habitats (Reed 1977). It is indigenous to North America but is now dispersed throughout the tropical regions of Malaysia, India, Pakistan, and the Philippine Islands (Anonymous 1967; Reed 1977). This plant is grown as an ornamental, and its leaves and seeds have been used for medicinal purposes (Chopra et al. 1956).

Plant pathogens have infection processes that may circumvent plant defense mechanisms. Several common plant defense mechanisms are known, but most of this knowledge has arisen from the study of crop-pathogen interactions with very little attention to weed-pathogen interactions (Hoagland 1990a). Such interactions are important in developing protocols for biological control of weeds with plant pathogens. Recently, investigations concerning the biochemical interactions of Alternaria crassa (Sacc.) Sands and $A$. cassiae for jimsonweed (Datura stramonium L.) and sicklepod, respectively, have shown that phenylalanine ammonia-lyase (PAL) and phenolic products regulated by $\mathrm{PAL}$ increase in response to infection (Hoagland 1990b; Hoagland and Boyette 1994). To provide further insight into defense mechanisms of plants challenged by $A$. cassiae, and due to the importance of pathogen-plant interactions, the following studies were undertaken. The objectives were : (i) to determine if $C$. alata is within the host range of $A$. cassiae, (ii) to evaluate the infectivity and injury caused by inundative spore levels of this bioherbicide, and (iii) to examine PAL activity and soluble hydroxyphenolic levels in treated and untreated $C$. alata seedlings to assess their role in plant defense against this pathogen.

\section{MATERIALS AND METHODS}

\section{Plant material and culture}

Seeds of $C$. alata were obtained from a local nursery and planted in a potting mixture consisting of vermiculite and peat $(1: 1 ; \mathrm{vol}: \mathrm{vol})$ moistened with dilute N-P-K (20-20-20) solution. Seed trays were placed in a growth chamber (14-h d, $300 \mu \mathrm{mol} \mathrm{m}{ }^{-2} \mathrm{~s}^{-1}$ PAR, $30^{\circ} \mathrm{C}$; 10 -h night, $25^{\circ} \mathrm{C}$ ). Plants were grown for various times up to 2-6 wk before testing.

\section{Spore preparation and inoculation}

Spores were prepared in an aqueous emulsion of soybean oil and distilled water (1:1; vol:vol). Plants were uniformly sprayed with the spore emulsion at $10^{5}$ or $10^{6}$ spores $\mathrm{mL}^{-1}$, placed in a dew chamber for $12 \mathrm{~h}$, then moved to a growth chamber with the environmental conditions described above. Control plants received emulsion without spores. Plants were examined at various intervals over a 6-d period and ratings of disease symptomatology and severity were made. 
Leaves stained with lactophenol blue were examined under a microscope to determine germination and growth of spores and mycelial production (Tuite 1969). Tests were made on plant age vs. mycoherbicide efficacy and on spore concentration vs. mycoherbicide efficacy. Sicklepod plants were also tested in side-byside treatments for direct comparison in some experiments.

\section{Injury rating of $\boldsymbol{A}$. cassiae on Cassia spp. plants}

The effects of $A$. cassiae on $C$. alata and C. obtusifolia were examined in side-byside evaluations. Visual ratings were made using an injury scale: $0=$ normal growth (no symptoms); 1 = symptoms barely discernible; 2 = symptoms clearly visible (multiple lesions, but less than $50 \%$ of leaf surfaces affected); $3=$ moderate symptoms (about $50 \%$ of leaf surfaces with lesions, some necrosis and chlorosis becoming apparent); 4 = severe symptoms (about $75 \%$ of leaf surfaces with expanding lesions, increased necrosis and chlorosis); $5=$ extremely severe symptoms (about $95 \%$ of leaf surfaces with lesions, some leaf abscission, lesions and necrosis appearing on some stems); 6 = leaves dead, increased leaf abscission, stem lesions, and necrosis.

\section{Soluble hydroxyphenolics extraction and assay}

Hydroxyphenolic compounds were extracted from $C$. alata plants with methanol $(100 \%)$. Excised tissue was homogenized with methanol at $0-4^{\circ} \mathrm{C}$ using a high-speed homogenizer. Homogenates were then centrifuged at $20000 \mathrm{~g}, 15 \mathrm{~min}$ at $0-4^{\circ} \mathrm{C}$. Supernatants were quantitatively assayed for total hydroxyphenolic content using a colorimetric procedure with the Folin-Ciocalteu reagent (Singleton and Rossi 1965). Absorbance at $756 \mathrm{~nm}$ was measured and the phenolic concentration determined using a standard curve based on colorimetric analysis of an equimolar mixture of caffeic acid, chlorogenic acid, $p$-coumaric acid, and quercetin.

\section{PAL extraction and assay}

PAL activity was extracted, partially purified, and assayed as described elsewhere (Hoagland et al. 1979). Enzyme activity is expressed in milliunits $(\mathrm{mU})$; a
$\mathrm{mU}$ is defined as the amount of enzyme required to produce $1 \mathrm{nmol} \mathrm{min}^{-1}$ of $t$-cinnamic acid from L-phenylalanine at $30^{\circ} \mathrm{C}$ (Havir and Hanson 1970). Enzyme activity is expressed as specific activity ( $\mathrm{mU} \mathrm{mg}^{-1}$ protein), and protein concentration was determined using UV spectrophotometry (Murphy and Kies 1960).

\section{Experimental design and statistics}

The experimental design used was a completely randomized design, and all tests were duplicated or triplicated (4-8 plants replication $\left.{ }^{-1}\right)$. The experiment was repeated in time. Data were subjected to ANOVA (SAS Institute Inc. 1989) and mean comparisons performed using Fisher's protected LSD.

\section{RESULTS}

\section{Infectivity studies}

C. alata seeds germinated well, and growth proceeded relatively rapidly. This species can attain heights of $2 \mathrm{~m}$, and this was observed in field-grown plants after about $3 \mathrm{mo}$ (Fig. 1). A. cassiae $\left(10^{6}\right.$ spores $\left.\mathrm{mL}^{-1}\right)$ was able to infect plants

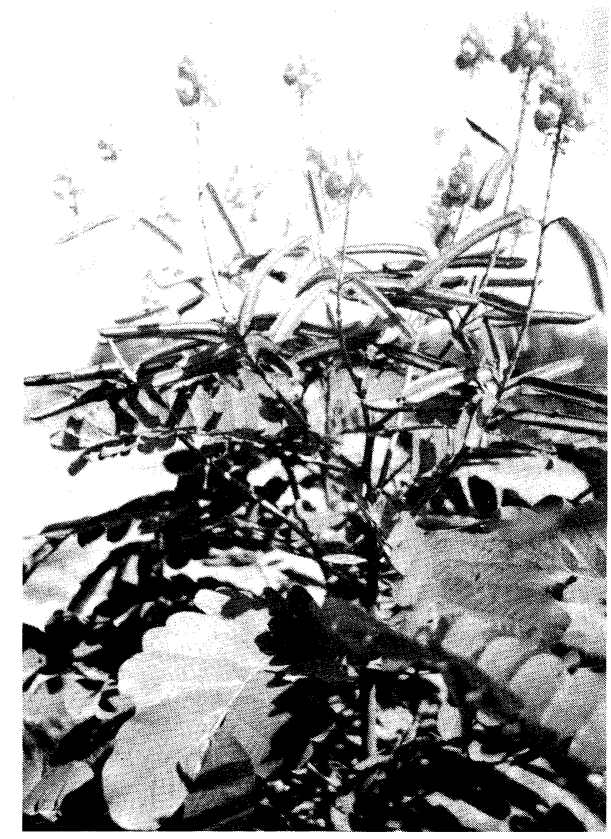

Figure 1. Field-grown $C$. alata, flowering about 3 mo after emergence. 
A
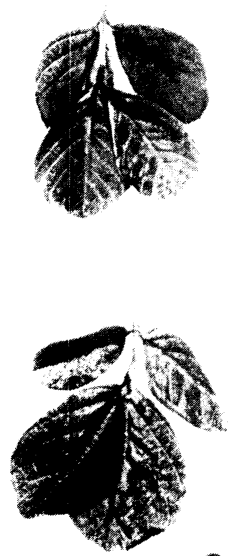

C. alata

Control
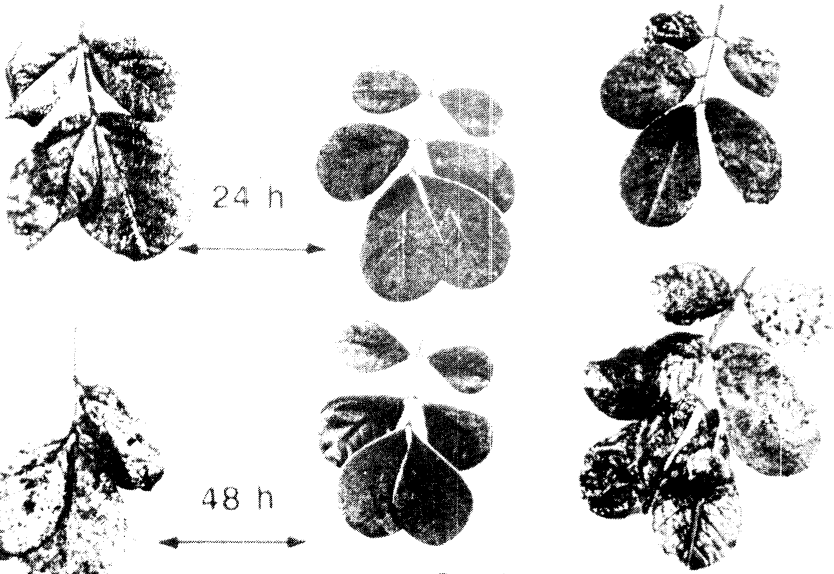

C. obtusifolia

Control

\section{Treated}

Figure 2. Chlorosis and necrotic leaf lesions in $C$. alata and $C$. obtusifolia leaves caused by A. cassiae. A : 24 HAT; B : 48 HAT.

of this size, but damage to these large plants was minimal (data not shown). However, when $A$. cassiae spores $\left(10^{6}\right.$ spores $\left.\mathrm{mL}^{-1}\right)$ were applied to 3-wkold sicklepod and $C$. alata seedlings, spores germinated and formed mycelia and appressoria on leaf surfaces after $12 \mathrm{~h}$ (data not shown) and injury was apparent in both species at 24 and 48 hours after treatment (HAT) (Fig. 2). Infection, lesions, necrosis, and some chlorosis were observed in both species, mostly on the leaf surfaces, as opposed to stems. The two species have similar leaf size and shape at young growth stages (compare Fig. 2 a,b). These results clearly indicate that $C$. alata is susceptible to this pathogen when applied in an augmentative manner.

Injury by $A$. cassiae on this new host (and on sicklepod for comparison) was further evaluated by challenging plants in the 3-leaf growth stage with $10^{6}$ spores $\mathrm{mL}^{-1}$ and rating the injury over a 6-d time course (Fig. 3). C. alata was somewhat more resistant to this spore concentration than was sicklepod. This was especially true later in the time course, since some $C$. alata plants produced new leaves that exhibited little or no injury. By 100-144 HAT, the lesions caused by $A$. cassiae on $C$. obtusifolia were often observed to be round and about 1-mm diam or less, whereas on C. alata, lesions were larger and oblong or angular $(2.0 \mathrm{~mm} \times 4.0 \mathrm{~mm})$.

C. alata was tested at various growth stages with $10^{5}$ spores $\mathrm{mL}^{-1}$ and rated at three different times over a 144-h period (Fig. 4). Infection was clearly visible 12 HAT in the young, 1- to 2-leaf stage seedlings. Injury or death of these plants had occurred by 72 HAT. Plants had not recovered 144 HAT. Older plants in the 4- to 5-leaf stage were less susceptible to the fungus at these respective rating

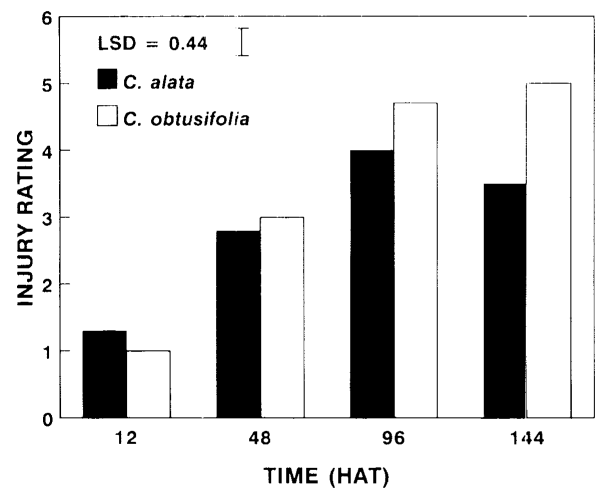

Figure 3. Injury levels caused by $A$. cassiae $\left(10^{6}\right.$ spores $\left.\mathrm{mL}^{-1}\right)$ on $C$. alata and C. obtusifolia over a 144-h time course. 


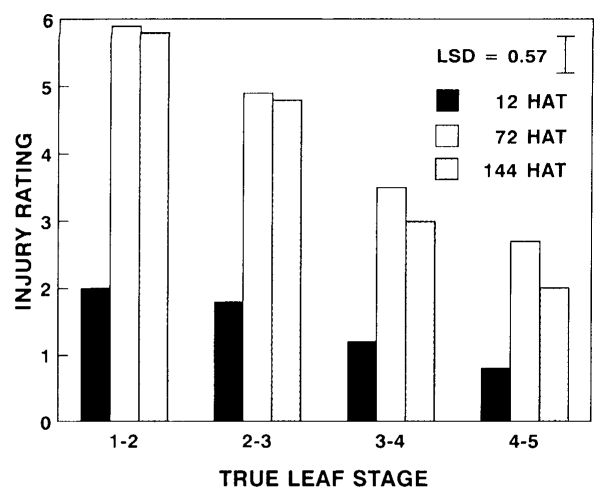

Figure 4. Injury levels caused by $A$. cassiae $\left(10^{5}\right.$ spores $\left.\mathrm{mL}^{-1}\right)$ to $C$. alata plants at various growth stages at three rating periods.

periods. As before, the older plants were able to resist and outgrow some of the bioherbicidal effects. However, substantial leaf abscission was observed in all plants, indicating some bioherbicidal effects, even against older plants. In final infectivity tests, $C$. alata was sprayed with A. cassiae spores, infection was allowed to proceed, and pathogen isolation from leaf lesions was performed. The isolates from this procedure were grown on potato dextrose agar and spores from these plate cultures infected young $C$. obtusifolia and $C$. alata seedlings in a manner analogous to the original $A$. cassiae spores used in this study (data not shown).

\section{Effects of $A$. cassiae on $C$. alata phenolic metabolism}

Extractable PAL activity, on a specific activity basis, generally increased slightly over time in shoots of the emulsiontreated $C$. alata seedlings (Fig. 5). PAL activity in shoots of $A$. cassiae-treated plants rose dramatically above control levels from 17 to 96 HAT and was about 3.5-fold above control levels 40 HAT. Increased PAL activity in pathogen-treated plants declined somewhat after 40-96 h, but still remained more than 2 -fold above control levels.

Methanolic extracts of $C$. alata seedlings were analyzed for total soluble hydroxyphenolic compound (PAL product) content in A. cassiae-treated and nontreated seedlings (Fig. 6). There was a general increase in soluble hydroxyphe-

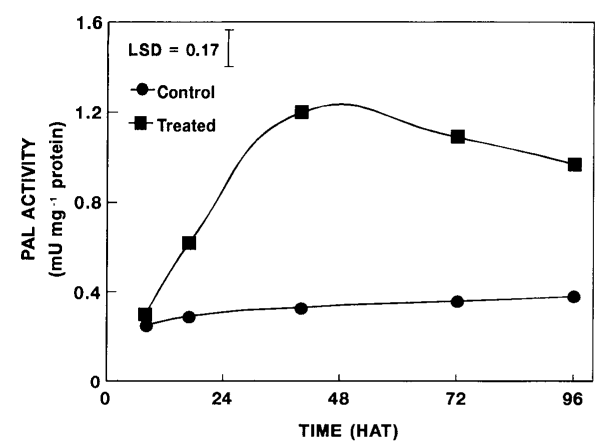

Figure 5. Specific activity of extractable PAL activity in $A$. cassiae-treated $C$. alata seedlings.

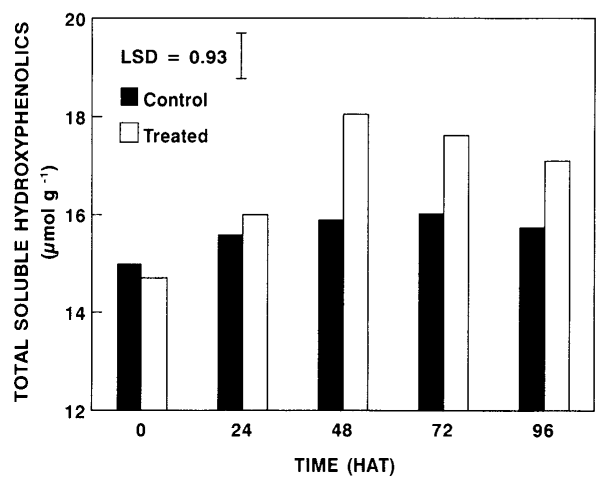

Figure 6. Soluble hydroxyphenolic compound levels in $A$. cassiae-treated $C$. alata seedlings, expressed on a fresh weight basis.

nolic content of non-treated seedlings over the time course. This trend was also observed in the $A$. cassiae-treated seedlings, but levels were significantly higher than those in non-treated plants 48-96 HAT.

\section{DISCUSSION}

A. cassiae was more pathogenic to younger $C$. alata plants. This is generally typical of both herbicidal and bioherbicidal activity. Older plants are more tolerant and have more thoroughly developed cuticles, wax accumulation, etc., that can lower retention and penetration of molecules and mycelia. The fact that infection of, and injury to, $C$. alata caused by A. cassiae was generally more immediate and severe in the leaves than in stem tissue may be a function of the relatively greater retention of spore-containing 
emulsion droplets on the former plant organ. Stems are also more woody than leaf tissue. Differences in lesion appearance in $C$. alata and $C$. obtusifolia could be caused by quantitative and qualitative differences in wax formation on leaf surfaces, or by nyctitropic and thigmotropic movements (caused by changes in photo-intensity, spraying, or transporting of plants during spray application) observed in both species. Wax formation, pubescence, and angular disposition of a leaf surface could affect spore-emulsion droplet flow, and thereby influence spore concentration, germination, and infectivity. Similar principles are involved in herbicide retention. The inherent wettability of the leaf surface, (influenced by leaf pubescence and waxiness, and the surface tension of the formulation applied are major factors in foliar retention of herbicides (Anderson 1983).

The effects of $A$. cassiae on phenolic metabolism in C. alata were quite similar to those reported for A. cassiae-C. obtusifolia interactions (Hoagland 1990b). Both PAL activity and PAL product (soluble hydroxyphenolic) levels were increased within hours of treatment. But, as in C. obtusifolia, increased PAL activity and phenolic production in $C$. alata did not confer resistance to $A$. cassiae, at least at these applied spore levels and to plants of a young age. Older plants (> 6-wk old) or mature flowering plants are relatively immune to these spore levels under these conditions, which may suggest that this phenolic defense mechanism is sucessful.

Phenolics have been demonstrated to play a role in plant resistance to Alternaria spp. For example, cotton seedlings resistant to $A$. macrospora Zimm. possess a higher phenolic content than susceptible varieties (Bashan 1986). Phenolic extracts from infected plants could also inhibit growth of this fungal pathogen in vitro. Phenolic metabolism of two jimsonweed varieties was increased when plants were challenged by a pathogen (A. crassa) that has potential as a mycoherbicide (Hoagland and Boyette 1994). The presence of phenolic plant constitutents may ward off pathogen infection, and older plants may have larger pools of such compounds. C. alata has been shown to possess relatively large amounts of flavonoids and anthroquinones (Gupta and Singh 1991). Elicitation by $A$. cassiae of a flavonoid in sicklepod has recently been reported (Sharon and Gressel 1991). This compound had antifungal activity against $A$. cassiae and A. alternata (Fr.) Keissler.

Pathogens initially thought to have a specific host range have later been shown to infect a wider range of plants. One example is the fungal pathogen Colletotrichum gloeosporioides (Penz.) Penz. et Sacc. f.sp. aeschynomene which causes an anthracnose of the weed northern jointvetch [Aeschynomene virginica (L.) B.S.P.] (Daniel et al. 1973). The pathogen was used as a mycoherbicide and was initially thought to be specific for $A$. virginica and $A$. indica $L$. after field and greenhouse host range tests (Daniel et al. 1973). It was later shown to infect some but not all cultivars of peas (Pisum sativum L.), lupines (Lupinus spp.), sweet pea (Lathyrus spp.), and broad bean ( $\mathrm{Vi}$ cia faba L.), proving a wider host range for this pathogen, even though species from 20 crop genera were immune (TeBeest 1988).

It is quite possible that $A$. cassiae could also infect some other Cassia species and species unrelated to Cassia. Considering $C$. alata as an ornamental, the use of $A$. cassiae as a mycoherbicide to control $C$. obtusifolia could perhaps increase pathogen levels sufficiently in nearby fields to endanger or cause damage to a non-target species. On the other hand, there are many examples of plants introduced as beneficials or ornamentals that have escaped and become serious weed problems. Theoretically, this is possible with C. alata, and in that case, the mycoherbicide $A$. cassiae could be a biocontrol agent.

The overall results of these studies of infectivity and phenolic metabolism of A. cassiae-C. alata are very similar to those reported for this pathogen's interactions with C. obtusifolia (Walker and Riley 1982). Four phytotoxins have been isolated from A. cassiae. However, they were generally more phytotoxic to corn (Zea mays L.) and crabgrass (Digitaria spp.) than to sicklepod (Hradil et al. 1989). These two 
Cassia species appear to be equally affected by these phytotoxins.

A. cassiae is pathogenic to $C$. alata. It can infect and cause severe damage or death to $C$. alata seedlings at mycoherbicidal concentrations $\left(10^{5}-10^{6}\right.$ spores $\left.\mathrm{mL}^{-1}\right)$ if the plants are relatively young $(\leq 3-w k$ old). This information shows an extended host range of this pathogen to three species in the genus Cassia (C. obtusifolia, C. occidentalis, and C. alata). This data is important in understanding biological control of weeds with plant pathogens and in understanding biochemical defense mechanisms of weeds against pathogens.

\section{ACKNOWLEDGEMENTS}

The author thanks Ms. Velma Robertshaw for excellent technical support, and Greenville Garden Center, Greenville, Mississippi, for kindly providing seeds of C. alata. Mycogen Corporation generously provided $A$. cassiae spores for this project.

\section{REFERENCES}

Anderson, W.P. 1983. Entry of herbicides into plants. Pages 477-501 in Weed Science: Principles, $2^{\text {nd }}$ Edition. West Publ. Co., St. Paul, Minnesota.

Anonymous. 1967. Identification of plants on Malayan estates. Cassia species. Rubber Res. Inst., Planter's Bull. 89 : 53-65.

Bashan, Y. 1986. Phenols in cotton seedlings resistant and susceptible to Alternaria macrospora. J. Phytopathol. $116: 1-10$.

Buchanan, G.A., and E.R. Burns. 1971. Weed competition in cotton. I. Sicklepod and tall morningglory. Weed Sci. 19 : 576-579.

Chopra, R.N., S.L. Nayar, and I.C. Chopra. 1956. Glossary of Indian medicinal plants. Council of Scientific and Industrial Research (CSIR), New Delhi, 329 pp.

Daniel, J.T., G.E. Templeton, R.J. Smith, Jr., and W.T. Fox. 1973. Biological control of northern jointvetch in rice with an endemic fungal disease. Weed Sci. 21 : 303-307.

Gossett, B.J. 1981. Sicklepod - how to control it in soybeans. Weeds Today $12: 29$ 30.
Gupta, D., and J. Singh. 1991. Flavonoid glycosides from Cassia alata. Phytochemistry $30: 2761-2763$.

Hauser, E.W., G.A. Buchanan, and W.J. Ethredge. 1975. Competition of Florida beggarweed and sicklepod with peanuts. I. Weed-free maintenance and weed competition. Weed Sci. 23 : 368-372.

Havir, E.A., and L.R. Hanson. 1970. L-phenylalanine ammonia-lyase (potato tubers). Pages 575-581 in $\mathrm{H}$. Tabor and C.W. Tabor (eds), Methods in enzymology 17A. Acad. Press, New York.

Hoagland, R.E. 1990a. Biochemical responses to pathogens. Pages 87-113 in R.E. Hoagland (ed.), Microbes and microbial products as herbicides, Am. Chem. Soc. Sym. Ser. No. 439. ACS Press, Washington, DC.

Hoagland, R.E. 1990b. Alternaria cassiae alters phenylpropanoid metabolism in sicklepod (Cassia obtusifolia). J. Phytopathol. 130 : 177-187.

Hoagland, R.E., and C.D. Boyette. 1994. Pathogenic interactions of Alternaria crassa and phenolic metabolism in jimsonweed (Datura stramonium L.) varieties. Weed Sci. $42: 44-49$

Hoagland, R.E., S.O. Duke, and C.D. Elmore. 1979. Effects of glyphosate on metabolism of phenolic compounds. III. Phenylalanine ammonia-lyase activity, free amino acids, soluble protein, and hydroxyphenolic compounds in axes of dark-grown soybeans. Physiol. Plant. 46 : 357-366.

Hradil, C.M., Y.F. Hallock, J. Clardy, D.S. Kenfield, and G. Strobel. 1989. Phytotoxins from Alternaria cassiae. Phytochemistry $28: 73-75$.

Jurair, A.M.N., and A. Khan. 1960. A new species of Alternaria on Cassia holsericea Fresem. Pak. J. Sci. Indust. Res. 3 : 71-72.

Murphy, J.B., and M.W. Kies. 1960. Note on the spectrophotometric determination of protein in dilute solutions. Biochem. Biophys. Acta 45 : 382-384.

Reed, C.F. 1977. Economically important foreign weeds. Agriculture Handbook No. 498. U.S. Dept. Agric., Washington, DC, $746 \mathrm{pp}$.

SAS Institute Inc. 1989. SAS user's guide : Statistics. 6 Ed. SAS Institute Inc., Cary, North Carolina. 
Sharon, A., and J. Gressel. 1991. Elicitation of a flavonoid phytoalexin accumulation in Cassia obtusifolia by a mycoherbicide: estimation by $\mathrm{AlCl}_{3}$-spectro-fluorimetry. Pestic. Biochem. Physiol. 41 : 142-149.

Singleton, Y.L., and A.J. Rossi, Jr. 1965. Colorimetry of total phenolics with phosphomolybdic-phosphotungstic acid reagents. Am. J. Enol. Vit. 16 : 144-158.

TeBeest, D.O. 1988. Additions to host range of Colletotrichum gloeosporioides f. sp. aeschynomene. Plant Dis. 72 : 16-18.

Tuite, J. 1969. Page 204-223 in Plant pathological methods : fungi and bacteria. Burgess Publ. Co., Minneapolis, Minnesota.
Walker, H.L. 1982. Seedling blight of sicklepod caused by Alternaria cassiae. Plant Dis. 66 : 426-428.

Walker, H.L., and C.D. Boyette. 1985. Biocontrol of sicklepod (Cassia obtusifolia) in soybeans (Glycine max) with Alternaria cassiae. Weed Sci. 33 : 212-215.

Walker, H.L., and J.A. Riley. 1982. Evaluation of Alternaria cassiae for the biocontrol of sicklepod (Cassia obtusifolia). Weed Sci. $30: 651-654$. 